\title{
THE POLITICS OF IDENTIFICATION IN THE CONTEXT OF GLOBALIZATION
}

\author{
V. SPIKe PETERson \\ Department of Political Science, University of Arizona, Tucson, AZ 85721, USA
}

\begin{abstract}
Synopsis - Ironically, globalization dynamics reveal the centrality of private sphere activities and their gendered politics to processes of identification, structural inequalities, and political action. Bringing the family/household into relation with nation-states and global capitalism (and vice versa) exposes the pervasive and interactive power of gender(ed) identifications and divisions of labor. Today's global restructuring constitutes an erosion of nation-state power vis-à-vis managing national economies, protecting citizen's rights, and delivering social services. Situating gender and nationalism in this global context problematizes the accountability of nation-states and the pursuit of nationalism and other state-centric identities.
\end{abstract}

\begin{abstract}
All our fates are linked within this [global economic] system but our precise position in it depends on a multiplicity of factors such as our gender, class background, colour, ethnicity, caste, whether we live in a rich industrially advanced society or a poor country of the Third World. Given the global nature of this system it is axiomatic that questions of feminism cannot be framed without reference to this international context. (Brah, 1991, p. 168)
\end{abstract}

This article takes the global context as its starting point. ${ }^{1}$ It addresses the themes of the special issue by situating the politics of gender and group identifications - of which nationalism is the prominent example - in the context of global restructuring. The gendered politics of identification processes as they are constituted by group formation and reproduction under

The author would like to thank Nira Yuval-Davis, Maria Mies, and Cynthia Enloe for political and intellectual inspiration, Barbara Einhorn for timely and significant encouragement, Stacey Mayhall and Jacqui True for research and personal support, the feminist international relations community for solidarity and hope, and Karen Carlson for the loving work (multiple senses) that she does. The author also thanks the Office of the Vice President for Research and the School of Social and Behavioral Sciences, University of Arizona for research support. conditions of masculine dominance are examined first. These processes are explored in the context of the family/household where gender and group identities are established and where divisions of labor result in gender-differentiated relations of power. Next, these relations of power are examined in the context of nationstates where masculinist projects operate both internally (in relation to family/households) and externally (in relation to other nations). Households and states are then situated in the context of contemporary global restructuring. In this context, informal sector activities (based on the family/household) are increasingly salient, the capacity of states to manage their national economies is deeply eroded, and statecentric identities (like nationalism) are rendered structurally problematic. Bringing the household into relation with nation-states and global capitalism reveals not only the structural and ideological linkages among these conventionally separated spheres but also demonstrates the pervasiveness and power of gender. Stated differently, the article brings the private sphere of the family/household, the public sphere of state governments and the economic sphere of global capitalism into relation to suggest how changing (gendered) divisions of identity and labor are changing (gendered) divisions of power and vice-versa. 


\section{THE (GENDERED) POLITICS OF GROUP IDENTITIES AND IDENTIFICATION ${ }^{2}$}

Feminists have critically examined the politics of identification because (a) gender shapes not only who we are but the world(s) we live in, (b) resistance to changing our personal (gender) identities obstructs feminist movement, (c) the identity of the modern subject is not genderneutral but masculine (and typically European), and (d) feminist identity is itself problematic given the diversity (non-identity) among women. Fifth, identity groups most closely associated with political power have also been historically based on gender inequality. As members of these groups, women have interests in their success, including the group's acquisition of political power vis-à-vis competitors. But, insofar as the groups reproduce masculine dominance, identification with and support for them is problematic for feminists. This dilemma informs much of the discussion to follow.

\section{How are groups and their identities reproduced?}

Groups may be bounded by any number of criteria: ethnicity, a common history, culture, territory, or shared purpose. While objective attributes may be featured in bounding some groups, $\mathrm{I}$ follow Iris Young in arguing that "a social group is defined not primarily by a set of shared attributes, but by a sense of identity" (Young, 1990, p. 44). The question addressed here is: once group formation has taken place, ${ }^{3}$ how is the reproduction of the group, which entails some shared sense of identity, ensured? That is, in the absence of any biological connection beyond some females bearing and breastfeeding infants, how are social relations institutionalized, becoming marked by group coherence, identification with the group itself, and continuity through time?

Jill Vickers argues that patriarchal social relations can be interpreted as one way of "constructing enduring forms of social organization, group cohesion and identity" (Vickers, 1990, p. 483). ${ }^{4}$ Men, who lack any immediate biological connection, appropriate an abstract concept of the blood-tie and employ it to promote bonding among males and loyalties to a male-defined group extending beyond the mother-infant bond. Implementation of this strategy involves regulating sexual practices and instituting social relations that reproduce group identity based on these male-oriented needs.
To the extent that women are denied agency in the definition of group interests and compelled to comply with male-defined needs, their freedom and autonomy are limited. This pattern of domination has historically been accompanied by denying women the authoritative status of personhood accorded to those who are empowered as group decision makers. In sum, the coherence and continuity of the group and the gender hierarchy it imposes - are "maintained and secured only by limiting the autonomy, freedom of choice and social adulthood of the group's physical and social reproducers" (Vickers, 1990, p. 482).

What Vickers calls the "battle of the cradle" is about regulating under what conditions, when, how many, and whose children women will bear. The forms it takes are historically specific, shaped by socio-religious norms, technological developments, economic pressures, and political priorities. The common feature is promoting reproduction of one's own group on the assumption of competition with other groups. Depending on the type of group (e.g., territorial nations such as the United States and United Kingdom), this implicates women of different classes, ethnicities, and races in complex and context-specific ways. The common feature is a tendency to preclude women's identification with women as a group in favor of their identification with the (territorial, class, ethnic, race) group of which they are a member and which is based on male-defined needs.

The battle of the nursery is about ensuring that children born are bred in culturally appropriate ways. This involves the socio-cultural, legal, and coercive regulation of sexual liaisons so that membership boundaries are maintained. It also involves ideological reproduction through socialization of group members. Under patriarchal relations, women are the primary socializers of children and the household is the primary site of socialization. Here, women inculcate identities, beliefs, behaviors, and loyalties that are culturally appropriate and promote intergenerational continuity. This cultural transmission includes learning the "mother tongue," as well as the group's symbols, rituals, divisions of labor and world-views. Although the site of this socialization is largely the family/household, where sexual norms, kin and community-based obligations, and familial relations are focal, these identifications are extended beyond the household to structure how we understand - 
and relate to - sexual stereotypes, job expectations, exchange relations, social hierarchies, and authoritative power more generally.

\section{Nation-as-woman, woman-as-nation}

Assigned the identity of reproducers, it is women whose capacities and activities are privatized in the household and in the name of male-defined groups. But women also serve as symbolic markers of the group's cultural identity because men's distance from reproductive activities forces them to privilege imagined relations. As a result, the symbolic realm is elevated to strategic importance (Vickers, 1990, p. 484). Feminists have examined this dynamic especially in regard to women as symbols of the nation and as the cultural carriers of the ethnic group (Yuval-Davis \& Anthias, 1989; Moghadam, 1994).

From the familiar personification of natureas-female it is an easy slide to reading the nation-as-woman. This depicts the Motherland as spatial, embodied femaleness: The land's fecundity, upon which the people depend, must be protected by defending the body/nation's boundaries against invasion and violation by foreign males. But nation-as-woman is also a temporal metaphor: The rape of the body/nation not only violates frontiers but disrupts - by planting alien seed or destroying reproductive viability - the maintenance of the community through time. There is an additionally "potent" message in this patriarchal metaphor: Men who cannot defend their woman/nation against rape/invasion have lost their proprietary claim to that body, that land.

Another easy slide and we are reading the woman-as-nation. Here, woman signifies the boundaries of group identity, marking its difference from alien others. Assigned responsibility for reproducing the group through time, women are singled out as "custodians of cultural particularisms" and "the symbolic repository of group identity" (Kandiyoti, 1991, p. 434). Because symbols of cultural authenticity are jealously guarded, actual women face a variety of pressures to conform to idealized models of behavior. In Jan Jindy Pettman's (1992) words, women are "particularly susceptible to control in strategies to maintain and defend the [group's] boundaries. . . . Women's movements and bodies are policed, in terms of their sexuality, fertility, and relations with 'others' ... [and women are seen as] possessions, as those responsible for the transmission of culture and through its political identity" (pp. 5-6).

What emerges in this discussion is the centrality of gender hierarchy in processes of identification and group reproduction. Specifically, the reproduction of nationalist groups under patriarchal conditions involves a gendered (also class and often ethnic/race) division of power and labor that institutionalizes inequality or inequalities within the group: dividing women from men and from each other (insofar as their identification with women as a group is disrupted in favor of identification with the maledefined group). Moreover, intergroup hostility is institutionalized to the extent that identification with a single, essentialized group - the nation - is promoted at the expense of multiple, fluid identifications and transgroup solidarities.

What also emerges is the political significance of reproductive processes. Conventionally ignored as a dimension of the ostensibly apolitical private sphere, the power relations of reproduction fundamentally condition who we are (and who they are), how group cultures are propagated, and how groups/nations align (identify) themselves in cooperative, competing, and complementary ways. Insofar as these reproductive processes occur within the family/household, the latter is a crucial site of politics. Social relations within the family/household are then key to understanding the reproduction - and transformation - of groups and intergroup politics. These groups include nation-states themselves which, in fact, depend on properly functioning family/households to ensure their reproduction. On this view, transformations in the family/household have consequences for nation-states - and vice-versa. Seeing these linkages requires situating the family/household in relation to the state and global dynamics.

\section{THE (GENDERED) POLITICS OF NATION-STATES}

Cultural history, political orientation, and location in the global economy shape - and differentiate - the internal dynamics of states. But to ensure their continuity, all states must maintain a sufficient resource base to fund internal and external projects, defend their territorial integrity, and sustain their legitimacy against sub- and trans-national challenges. These processes require the social reproduction 
- historically based on family/households of both a numerically adequate and appropriately socialized population. Because all of these are gendered processes, we can observe gendered patterns of state-making even as states themselves vary tremendously (Peterson, 1992b, in press).

Liberal ideology notwithstanding, the state intervenes in private sphere - family/household - dynamics in part to impose centralized authority over birth rate patterns, property transmission, and reproduction of appropriately socialized family members, workers, and citizens. The means include laws circumscribing sexual behavior, control of women's reproductive rights, and the promotion (through state policies, public media, and educational systems) of gender, ethnic and race identifications, heterosexism, and particular family forms. The state's ideological promotion of hegemonic masculine (breadwinner) and feminine (dependent care-taker) identities in the household extends into the labor market, situating women in low-wage, low-profile servicing jobs. Moreover, states often promote a family wage model that elevates men's earnings, treats women's work as supplemental, and denies the reality of female-headed households.

Insofar as the state requires legitimation and is held accountable for the well-being of its members, its economic strategies must both generate sufficient centralized resources (to reproduce the state) and distribute sufficient resources (to produce well-being and promote ideological legitimation among its citizens). The difficulties of this balancing act for all states have been exacerbated by global restructuring (treated below) that emphasizes privatization and liberalization, which tend to weaken public programs and their delivery of social benefits. These are feminist issues because poverty is a feminist issue: Worldwide, women earn less (approximately 60\% of men's earnings) and own less (approximately $1 \%$ of the world's property) than men even as they are more responsible (up to $30 \%$ of households are headed by women) for themselves and society's children (United Nations, 1991).

And these are citizenship (political identity) issues because in contemporary states the wellbeing of individuals is linked to citizenship claims that mark who is inside (and outside) of the state's responsibility for protecting rights and providing welfare. The juridical-legal arena of state power defines who (based on group identities) is a citizen, what rights and duties citizenship entails, who may enter the state to work, in what capacity and with what legal and financial status, who may im/migrate, what language(s) and, therefore, cultures are privileged, and whose voices are politically represented.

State benefits and welfare policies are gendered not only because more women are poor (and women of nondominant ethnic groups are most often poorest) but also because current policies reproduce gendered (and ethnic/racist) divisions of labor and, therefore, power. For example, the United States maintains a gendered and racialized "two-tiered" system of socialwelfare benefits (Fraser, 1989; Nelson, 1984). An implicitly masculine entitlement tier, which has no social stigma, is oriented to individuals and tied to workforce participation (e.g., Social Security, disability insurance). An implicitly feminine means-tested tier, which stigmatizes welfare recipients, is oriented to households, and tied to combined household incomes (e.g., food stamps, Aid to Families with Dependent Children). Moreover, stigmatized welfare recipients are vulnerable to scapegoating by those who seek someone to blame for economic crises. The dilemma of course is that these programs, and welfare more generally in the context of masculinist states, institutionalize gendered divisions that systemically disempower women even as these programs are crucial for the survival of many women and may enable some forms of women's empowerment.

State and nationalist militarism produces, and is produced by, gendered identities and divisions of violence manifested both internally and externally. Whereas men are socialized (in the family as well as in the military) to be aggressive, competitive, protectors of the nation, and even life-takers, women are socialized to be passive, supportive, those in need of protection, and live-givers. Moreover, the costs of nationalist militarism are not just direct violence but (gendered and global) structural violence entailed by loss of social services (to military spending), increased prostitution (as a corollary of military bases and impoverished local populations), greater domestic violence (by militarized husbands), environmental degradation (from military actions), distorted labor markets (to suit military priorities), and long-term demands on women who care for those disabled - emotionally and physically - 
by formal and informal wars (Peterson \& Runyan, 1993).

\section{The power of gender identities, family/house- holds, and reproduction}

In sum, the nation-state is masculinist in how it constitutes the identities of workers (wage-earning or property-owning breadwinners) and citizens (rational, autonomous, individuals engaging in public/political sphere activities and strong, aggressive defenders protecting their women and their nation). Conversely, it ideologically constitutes women as unpaid wives and homemakers, affective, dependent household members, and passive supporters/followers of their men and their nation. This obscures the politics of gender inequality and identification processes - reproducing both individual (gender) and group (national but also class, ethnic, religious, etc.) identities in the family/household.

Although states clearly shape household relations and women's choices more generally, it is also the case that women and households constitute socio-cultural dynamics with pervasive effects. Within and outside of families, women and men engage in multiple activities that have a bottom up effect on gender, politics, and economics: through parenting and community activities (in neighborhoods, churches, schools, clubs), consumer choices and household investment strategies, grass-roots organizing and electoral activities, social movement participation (Carroll, 1989), and influence in the workplace. Whenever women speak out, claim equal rights, control their own reproduction, raise nonsexist and nonracist children, promote feminist consciousness, or engage in men's work, they disrupt gender stereotypes and masculinist practices. These disruptions have multiple effects.

Thus, women and households do not simply react to external - state and global economic - forces, but shape those forces. They act within the framework of masculinist power (which constrains women's autonomy) but strategize to "maximize security and optimize life options" in ways that continuously alter the terms of "patriarchal bargains" (Kandiyoti, 1988 , p. 274) and gender relations. The family/household is a key site because it is where we learn most about identities, hierarchies (of race, ethnicity, caste, class, gender, age, sexual orientation, religious affiliation), our positions within them, and how to reproduce, reconfigure, and resist them.

Two points warrant emphasis. First, insofar as they neglect the politics of gender and family/household relations, conventional explanations of group power and intergroup conflict are distorted and, therefore, inadequate. Masculinist dichotomies of reason-affect, public-private and productive-reproductive continue to frame these accounts, structuring not only what we study (men's public sphere activities) but also ways of studying (positivist methods, disciplinary divisions) that privilege categorical separations over constructs-in-relation (Peterson, 1992c). One consequence is our virtual ignorance of identification processes (considered emotional and private) that fuel today's powerful forces of fundamentalism and nationalism. We pay a very high price for these particular blinders. Another consequence is that the apparent separation of spheres of activity prevents our seeing how feminine and masculine stereotypes, group identities, social reproduction, family/household activities, public sphere power, economic productivity, internal and external forms of violence, welfare provision, and protection of rights are related and pervasively shaped by gender.

Second, it is the system of international states that renders nationalism so potent a force. In the international system (more accurately, in the ideological representation of that system), states are the only units accorded sovereign power over, and (ostensibly) freedom from intervention in, their territorially-based polities. Such freedom is actively, often militarily, sought by nationalist groups wishing to institutionalize and protect the priorities of their own group, often in reaction to subordination of those priorities under the yoke of some other group. Not surprisingly, state-centric identifications have powerful appeal, but their claim to territorial exclusivity renders them necessarily competitive and, therefore, problematic.

While nation-states promote gender and group identities and divisions of labor that are intended to support the state's reproduction, the "fit" is never complete: changes in material conditions, shared systems of meaning, and identifications are ongoing. This is particularly evident when we situate states, their families/ households, and nationalist politics in the context of globalization. 


\section{THE (GENDERED) POLITICS OF GLOBALIZATION}

The modern interstate (international) system is distinguished by the principle of sovereignty (marking the autonomy of individual states) and a state-centric construction of political identity (fostering state-led and state-seeking nationalist movements). But from a contemporary, even postmodern, perspective, state autonomy and political identity are belied by global economic dynamics, sub- and trans-national social movements, technologies, weapons, diseases, and pollution that transgress territorial boundaries. Hence, sovereignty is deeply eroded and political identity is not exclusively state-based. ${ }^{5}$ This does not mean the elimination of state power, rather its transformation in the context of global dynamics and transnational identifications.

These complex and sometimes contradictory dynamics are currently restructuring material conditions, reconfiguring social relations, and even rewriting the rules of the game. In spite of their daunting scale and complexity, we cannot afford to neglect these dynamics: they profoundly and increasingly shape national, local, family/household, and personal realities. In particular, these dynamics alter the strategies of all groups that are interested in gaining and/or transforming political power, whether nationalists, participatory democrats, or feminists.

This section situates family/households, states, and state-centric identities in relation to globalization as expressed in economic relations. The argument has two dimensions. First, a focus on gendered divisions of labor in the context of global restructuring reveals (perhaps more vividly than ever) how households, states, and global economies are linked both structurally (vis-à-vis production and reproduction, distribution of resources and power) and ideologically (vis-à-vis socialization practices, personal and group identifications). Second, global restructuring is also altering state power and national economic strategies, with effects on the delivery of welfare, the rights of workers, the politics of citizenship, and the political significance of state-centric identifications. In short, changing divisions of labor - which link households, states, and the global economy - are changing divisions of power (and vice-versa), with complex implications for iden- tity groups (including nationalists and feminists) and their political prospects.

\section{The family/household in relation to globalization}

Households and women's labor more generally remain invisible in economic analyses that privilege formal/productive/men's/paid labor over informal/reproductive/women's/unpaid labor. Conventionally, both liberal and marxist theories have largely taken women's work and informal sector activities for granted, simultaneously naturalizing the unequal gender relations this division of labor entails. But in recent decades, several developments have heightened the visibility of gender hierarchy in economic relations.

First, women's liberation movements generated demands and posed questions that exposed the limitations and masculinist premises of traditional accounts. This is especially welldocumented in feminist analyses of household labor, occupational segregation, economic development, and the gender of economic relations globally.

Second, global restructuring has shifted state policies away from Keynesian management of national economies to stabilization and structural adjustment strategies shaped by the global economy. Under these conditions ("flexibilization," deregulation, changing divisions of labor) household and informal sector activities increase in order to sustain social reproduction and the household increases in prominence as a focal point of local-national-global economics.

Third, movements toward "democratization" challenge us to understand the relationships among liberal-democratic regimes, nationalist movements, economic in/equalities, state-centric politics, and global hierarchies. Gender, ethnic, race, and class oppressions figure in these debates (Anthias \& Yuval-Davis, 1992; Young, 1990), especially as (householdbased) identification processes shape divisions of labor, intergroup conflicts, political strategies, and legitimation dynamics.

These developments simultaneously produce and are produced by shifting gender relations. For example, women's employment in exportprocessing zones is often based on gender stereotypes (docility, "nimble fingers") but the reality of being employed (access to wages and activities outside of the family/household) alters gender identities and social relations. Feminist 
approaches enable us to see how gendered divisions of labor both operate within and influence the economy at multiple sites: from the nursery through the state to the global factory.

These linkages are clearest in the work of theorists focusing on the world economy as a single system best understood in terms of a global division of labor that requires taking seriously the gendered division of labor constituted within (male-dominated) households (Smith, Wallerstein, \& Evers, 1984; Smith \& Wallerstein, 1992; Mies, 1986; Mies, BennholdtThomsen, \& von Werlhof, 1988). Exploitation in the latter is obscured by ideologies of sex difference that naturalize (depoliticize) women's oppression. The naturalization of gender hierarchy and exploitation within the household is then extended to hierarchies - of class, ethnicity, race, and nation - and the exploitative dynamics everywhere imposed by capitalist relations. In particular, "supposedly natural differences in capacities and needs on the basis of gender or of ethnicity or race then come to enter into economic relations as legitimizers of inequalities in class position" (Anthias \& YuvalDavis, 1992, p. 113; also, Smith, Collins, Hopkins, \& Muhammad, 1988).

Although definitions of the household vary, a key point is that the informal labor associated with the household (e.g., social reproduction, housework, subsistence production, petty commodities, semi-clandestine enterprises) is not simply a vestige of precapitalist forms but a structural feature of capitalist accumulation (Mies, 1986; Smith \& Wallerstein, 1992). The significance of this point is that informal sector activities are actually increasing around the world as global restructuring forces a contraction of formal sector opportunities. In general, the disparity between rich and poor is also increasing and is exacerbated by a polarization of formal and informal activities.

On the one hand, decision making and resources are concentrated in a small, privileged and male-dominated class (drawn especially from industrialized countries, but also from elites in developing countries) of educated and salaried managers, professionals, and owners of capital. On the other hand, the majority of the world's people engage in household/informal sector activities that are temporary, part-time, unprotected, nonorganized, and without benefits or state regulation. Maria Mies (1986) describes this development as "housewifization," where male workers can no longer anticipate salaried or unionized wage-labor employment and find themselves in the situation of housewives: atomized, unorganized, and economically insecure. By using housewifization to describe the plight of increasing numbers of men, Mies foregrounds the gender dimension and changing gender identifications imposed by capitalist accumulation.

From a world system perspective, states structure the family/household to meet their reproductive and productive needs and do so in the context of a global economy that shapes those needs. Joan Smith (1993) observes that "it is the state that legislates the existence of households and it is within households that struggles against the state and other collectivities are conducted" (p. 36). As the primary site of identity formation, households may reproduce or reconfigure particular - gender, ethnic, race, religious - identities, including their orientations toward work: how labor is divided, delegated, regarded, and differentially rewarded. As the site of social reproduction, households determine who and what gets reproduced, by whom, and how. As the site of informal sector activities, households both sustain capitalist dynamics (by ensuring noncommodified social reproduction) and resist capitalism's commodifying dynamic (by constituting activities that defy exploitation and refusing the commoditization of personal relations; Nash 1988, p. 14).

In short, households have always been crucial sites of power. While patriarchs, states, and capitalists have consistently held the greater part of that power, women (and subordinated others more generally) have not simply capitulated to structural inequalities but struggled against and bargained with agents of domination. In the context of globalization, patriarchs and states retain disproportionate power over women. But in that context, patriarchs and states themselves have to bargain with the dominating power of global capitalism. As different groups compete in the pursuit of profit, many patriarchs find themselves subject to "housewifization" and all states find themselves subject to transnational forces. These structural changes in state power not only change how states relate to households but also alter the politics of state-centric ideologies. 
States and nationalism in relation to globalization

The Bretton Woods system implemented under U.S. hegemony after World War II was designed to promote a liberalization of world trade and stabilization of international currencies. Nation-states were responsible for domestic economic policies, typically employing Keynesian management strategies aimed at controlling employment levels, regulating trade and monetary flows, and promoting consumption through redistribution and collective bargaining. Varieties of corporatism involved bargaining among representatives of government, business/industry, and organized labor in order to minimize social disruptions and their costs in productivity and national competitiveness. In short, state management of national economies both promoted growth-oriented capitalism (retaining competitive, exploitative social relations) and institutionalized worker's rights and welfare services. The legitimacy of the state became bound up with ensuring a favorable climate for business and protecting society's most vulnerable groups.

Since the late 1960 s, this postwar order has been beset by multiple crises and erosion of state control in favor of transnational forces. In the 1980 s and 1990 s, changes that have been subsumed under global restructuring marked a definitive shift away from the postwar Keynesian model of managed capitalism. On the one hand, the globalization of production marks a shift from large integrated facilities in developed countries to geographically dispersed activities comprising a "global assembly line." Increasing competition at all levels and rising labor costs in developed countries motivate transnational corporations to (re)locate labor-intensive assembly work in developing countries where governments may limit labor regulation and worker's rights in order to attract foreign investment. Capitalists and employers worldwide pursue flexible labor practices: dismembering large-scale enterprises in favor of more specialized and decentralized sites of production and assembly; subcontracting whenever possible; and increasing use of part-time, temporary workers who do not warrant benefits or long-term commitments. Housewifization is a consequence of these strategies.

On the other hand, the globalization of states marks a shift from state governments managing their economies and providing domestic welfare to states behaving "like unions forced to bargain with powerful groups of [transnational] capital" (Drache \& Gertler, 1991, pp. 8-9). In other words, the world economy, especially the power of global finance, forces states to respond, not lead, and to "reinvent government" in a new, internationalized mode. In contrast to ensuring welfare and protecting workers' rights, in this environment states are motivated to "discipline the workforce and constrain wage movements ... [while] providing industrial subsidies, tax concessions, and tax expenditures" in order to attract investments (Drache \& Gertler, 1991, p. 9).

These dynamics are gendered because housewifization is gendered and the erosion of the welfare state "reprivatizes" socially necessary labor at the expense of women. That is, when the state reduces social services, the costs are borne disproportionately (but not homogeneously) by women as the (structurally) most vulnerable and as the care-takers of society's dependent members. Moreover, competition for scarce jobs in developed and developing countries means that employers can "use statuses based on gender, age, and race/ethnicity to divide and exploit labor in the informal sector" (Ward, 1993, p. 48; Mitter, 1986). The latter pattern is exacerbated when labor migration increases competition for jobs and politicizes welfare provision (Anthias \& Yuval-Davis, 1992). In general, these conditions aggravate women's subordination and divisions among women, but they also politicize the interaction of gender, ethnicity, and race in contemporary divisions of labor and their operation in the household, state, and global economy.

In relation to nationalism, these dynamics are significant because they alter the social accountability of states and the politics of state-centric (territorial) identities, of which nationalism is the salient example. Here the linkages are less visible and raise more questions than they answer. But they are important questions in the context of competing group identities and the pursuit of a politics that takes social justice - and globalization - seriously.

Briefly, in response to group oppression, nationalist movements seek the status of states in order to ensure the (previously denied) wellbeing of their own group members. However, if global restructuring erodes the power of all states to ensure the well-being of their mem- 
bers, all state-centric identities are compromised in regard to social welfare promises. On this view, nationalism's progressive claims, which are already suspect in regard to reproducing gender inequalities, are additionally suspect in regard to securing and safeguarding the welfare of the group. ${ }^{6}$ Even more problematic, in what sense are any state-centric identities consistent with a politics of accountability in the context of global capitalism? What identifications are consistent with struggles for social justice? And what are the implications for an emancipatory feminist politics that takes difference seriously?

\section{CONCLUSION}

"The deconstruction of identity is not the deconstruction of politics; rather, it establishes as political the very terms through which identity is articulated" (Butler, 1990, p. 148). With the global context as its starting point, this article explored the power of gender(ed) identifications as they are constituted within and constitutively link households, states, and global capitalism. It argues that (gendered) power itself is relational and operates downward, upward, and multilaterally but not homogeneously. Because multiple oppressions are at work - sometimes overlapping, sometimes contradictory - emancipatory politics can rely on no single formula, universal subject, or utopian state but must engage a politics of difference. Rather than essentialist subjects and transhistorical claims, we are compelled to acknowledge our multiple identifications and critically examine their political effects (Grewal \& Kaplan, 1994; Gunew \& Yeatman, 1993).

Global contextualization is then crucial for two reasons. First, in contrast to the ahistorical and reductionist tendencies of positivist science, contextualization permits us to see how the world(s) we live in are made (not discovered) and how dimensions of social reality are interdependent (not categorically separate). Rather than hierarchical and masculinist dichotomies, understanding social life requires a relational orientation that embeds and embodies knowledge claims, that reveals the frameworks that constrain - but do not simply fix - actors' choices (Peterson, 1992c). The point to emphasize is that strategies (including identifications) and sets of constraints are interactive, continuously shaping each other; they are not static but always in process, always subject to reproduction and transformation.

Contextualization provides historical and systematic specification of the background or setting which constitutes (and is shaped by) particular relationships. It permits us to locate or situate diverse elements, that are marked by particularity and difference, in order to bring them into relation. Only by situating actors, identifications, discourses, institutions, and dynamics in context are we able to render nonessentialist critiques by asking: "Compared to what?" (What is the actual range of "choice"?) when evaluating particular strategies. This question reminds us that our choices (of objectives and identifications) are always shaped (but not fixed) by contingent factors; they are never neutral (but involve complex trade-offs), and they have intended and unintended consequences that continuously (re)constitute power relations (Peterson, 1992a, pp. 19-21).

Second, contextualization at the specifically global level is crucial for any contemporary effort to understand political identifications and their strategic implications. In today's world, global restructuring is arguably the most powerful dynamic shaping the everyday realities of states, transnational actors, business firms, households, and individual people. It constitutes an erosion of state power vis-à-vis managing national economies, protecting people's rights, and delivering social benefits. It, thus, raises extremely difficult questions about the nature of governance, the meaning of democratization, and the location of political accountability in a system premised on capitalist accumulation. These are the larger and unavoidable questions raised by the politics of identification in the context of globalization.

This article also brought households, states, and global capitalism into relation to expose the pervasive and interactive power of gender(ed) identities and divisions of labor. The point here is that changes in the division of labor (fueled, for example, by global restructuring, reduced social services, export processing zones, the computer revolution) constitute changes in identity (fueled, for example, by anticommunist, nationalist, feminist, fundamentalist, environmental movements) and vice-versa. Shifting power relations result and affect feminist strategies. Global contextualization enables feminists to situate particular strategies and assess their various trade-offs in relation to both other 
identifications (or bargains) and the constraints of the world economy.

What does all of this mean for nationalism as a state-centric identification? From a feminist perspective, state-making historically institutionalized and continues to naturalize masculine dominance. However, protections afforded by the liberal welfare state have not only ensured the survival of countless women (and others) but also enabled political reforms of varying but not insignificant - potency. Insofar as the choice is between welfare state accountability and the normative indifference of capitalist market relations (Harrington, 1992), state forms and their accountability mechanisms must be supported, even as we resist their masculinist (and elitist, racist) power relations.

But if, as this paper argues, global restructuring erodes even the moderate protection afforded by states, all state-centric strategies are compromised in regard to emancipatory politics. It is then not only states but capitalism as the basis of social relations that must be critically examined. Resistance to this critique is formidable, fueled in part by failure to draw distinctions among democratization, socialism, liberalism, and capitalism. Drawing such distinctions would situate accumulation and the pursuit of profit in context and reveal relationships that we need desperately to understand.

The profit motive that drives capitalism may fuel growth (for some) but we must ask, "Compared to what?" and examine the trade-offs (for others in the short run and all of us in the long run) that it imposes. The discrepancy between rich and poor is increasing, not decreasing, the conflicts fueled by inequality are expanding not diminishing, and the ecological viability of the planet is being threatened not sustained. One can be critical of these trade-offs without being an advocate of authoritarian socialism. But one cannot be critical of these trade-offs without being critical of gender(ed) identifications and other hierarchical divisions of labor that naturalize exploitation as a global given.

\section{ENDNOTES}

1. A global framework imposes its own limitations. I have neglected ethnicity, the many important ways in which it relates to gender and nationalism, and all non-statist political identifications (e.g., cultural movements, the European Community) in favor of focusing exclusively on territorially based state-led or state-seeking nationalism. I have also neglected empirical specificity in favor of sketching structural linkages and evolving dynamics among relatively undifferentiated categories. For example, "family/household" in this article refers broadly to social reproduction (sexual/familial relations, housework, informal sector activities) and important differences among households - also among states, economies, masculinities, women, transnational dynamics - are dangerously slighted in favor of discerning contextualized patterns.

2. By politics of identification I refer not to "identity politics" but to dynamic power relations constituting contexts, in this case, the global context, within which multiple and dynamic identities are situated. If social theories bring agency, order and change into intelligible relation, then identifications offer one way of "bridging" agency (subjectivity, identities, "microlevel"), order (structure, institutions "macro-level") and change (transformations - of agency and order - as effects of action mobilized by variance in identity salience and shifting identifications). On this view, identities are multiple, sometimes contradictory, and can be understood as strategies. The diverse literature underpinning this orientation is not addressed here; see the excellent account in Pignone (1992).

3. This paper focuses on identifications in relation to state-centric nationalism. It leaves aside the complex issues of how particular groups or forms of social organization (e.g., patriarchy) come into being in historical process.

4. With Vickers (1990), I emphasize that the development of gender hierarchy was neither "necessary" nor "inevitable" but represents one among numerous possibilities. Like states, racism, and nationalism, gender hierarchy is a complex, contingent, historical development that is not reducible to "nature." I elaborate on nationalism's gender-differentiated elements in Peterson (1994).

5. Of course, only the most powerful states ever enjoyed the illusion of autonomous management. In one sense, it is a matter of degree: Global capitalism has always constrained the autonomy of states, but unevenly, so that what appears as a new development for powerful states is an old pattern for "developing" and/or colonized states. In another sense, todays's globalization marks a structural shift: a transfer of power from multilateral economic institutions (controlled by powerful states) to transnational forces without familiar territorial links and therefore without accountability to any formal political authority.

6. Presumably, the power to privilege one's own group remains greater with states status than without it. But this ignores the context within which such power is achieved, to what emancipatory effect(s), and at whose expense.

\section{REFERENCES}

Anthias, Floya, \& Yuval-Davis, Nira. (1992). Racialized boundaries. London: Routledge.

Brah, Avtar. (1991). Questions of difference and international feminism. In Jane Aaron \& Sylvia Walby (Eds.), Out of the margins (pp. 168-176). London: Falmer Press.

Butler, Judith. (1990). Gender trouble: Feminism and the subversion of identity. New York: Routledge. 
Carroll, Berenice A. (1989), "Women take action!" Women's direct action and social change. Women's Studies International Forum, 12(1), 3-24.

Drache, Daniel, \& Gertler, Meric S. (Eds.). (1991). The new era of global competition. Montreal, Canada: McGill-Queen's University Press.

Fraser, Nancy. (1989). Unruly practices: Power, discourse, and gender in contemporary social theory. Minneapolis, MN: University of Minnesota Press.

Grewal, Inderpal, \& Kaplan, Caren (Eds.). (1994). Scattered hegemonies: Postmodernity and transnational feminist practices. Minneapolis, MN: University of Minnesota Press.

Gunew, Sneja, \& Yeatman, Anna (Eds.). (1993). Feminism and the politics of difference. Boulder, $\mathrm{CO}$ : Westview Press.

Harrington, Mona. (1992). What exactly is wrong with the liberal state as an agent of change? In V. Spike Peterson (Ed.), Gendered states (pp. 65-82). Boulder, CO: Lynne Rienner Press.

Kandiyoti, Deniz. (1988). Bargaining with patriarchy. Gender \& Society, 2(3), 274-290.

Kandiyoti, Deniz. (1991). Identity and its discontents: Women and the nation. Millennium, 2O(3), 429-443.

Mies, Maria. (1986). Patriarchy and accumulation on a world scale: Women and the international division of labour. London: Zed Books.

Mies, Maria, Bennholdt-Thomsen, Veronika, \& von Werlhof, Claudia. (1988). Women: The Last Colony. London: Zed Books.

Mitter, Swasti. (1986). Common fate, common bond: Women in the global economy. London: Pluto Press.

Moghadam, Valentine M. (Ed.). (1994). Gender and national identity: Women and politics in Muslim societies. London: Zed Books.

Nash, June. (1988). Cultural parameters of sexism and racism in the international division of labor. In Joan Smith, Jane Collins, Terence K. Hopkins, \& Akbar Muhammad (Eds.), Racism, sexism, and the world-system (pp. 11-36). New York: Greenwood.

Nelson, Barbara J. (1984). Women's poverty and women's citizenship. Signs, 10(2), 209-231.

Peterson, V. Spike. (1992a). Introduction. In V. Spike Peterson (Ed.), Gendered states: Feminist (re)visions of international relations theory (pp. 1-29). Boulder, $\mathrm{CO}$ : Lynne Rienner Publishers.

Peterson, V. Spike. (1992b). Security and sovereign states: What is at stake in taking feminism seriously? In V. Spike Peterson (Ed.), Gendered states: feminist (re)visions of intemational relations theory (pp. 31-64). Boulder, CO: Lynne Rienner Publishers.
Peterson, V. Spike. (1992c). Transgressing boundaries: Theories of knowledge, gender, and international relations. Millennium, 21(2), 183-206.

Peterson, V. Spike. (1994). Gendered nationalism. Peace Review, 6(1), 77-83.

Peterson, V. Spike. (in press). Seeking world order beyond the gender order of global hierarchies. In Robert W. Cox (Ed.), The new realism: Perspectives on multilateralism and world order. London: Macmillan.

Peterson, V. Spike, \& Anne Sisson Runyan. (1993). Global gender issues. Boulder, CO: Westview Press.

Pettman, Jan Jindy. (1992). Women, nationalism and the state: Towards an international feminist perspective. Occasional Paper 4 in Gender and Development Studies, Asian Institute of Technology, Bangkok, Thailand.

Pignone, Mary Margaret. (1992). On becoming a global citizen: Praxis in identity politics. Unpublished doctoral dissertation, The American University, Washington, DC. Smith, Joan. (1993). The creation of the world we know: The world-economy and the re-creation of gendered identities. In Valentine M. Moghadam (Ed.), Identity politics and women (pp. 27-41). Boulder, CO: Westview Press.

Smith, Joan, Collins, Jane, Hopkins, Terence K., \& Muhammad, Akbar (Eds.). (1988). Racism, sexism, and the world-system. New York: Greenwood Press.

Smith, Joan, \& Wallerstein, Immanuel. (1992). Households as an institution of the world-economy. In Joan Smith \& Immanuel Wallerstein (Eds.), Creating and transforming households: The constraints of the worldeconomy (pp. 3-23). Cambridge, UK: Cambridge University Press.

Smith, Joan, Wallerstein, Immanuel, \& Evers, Hans-Dieter (Eds.). (1984). Households and the world-economy. Beverly Hills, CA: Sage.

United Nations. (1991). The world's women: 1970-1990. Trends and statistics. New York: Author.

Vickers, Jill McCalla. (1990). At his mother's knee: Sex/gender and the construction of national identities. In Greta Hoffmann Nemiroff (Ed.), Women and men: Interdisciplinary readings on gender (pp. 478-492). Toronto, Canada: Fitzhenry \& Whiteside.

Ward, Kathryn B. (1993). Reconceptualizing world system theory to include women. In Paula England (Ed.), Theory on gender, feminism on theory (pp. 43-68). New York: Aldine de Gruyter.

Young, Iris M. (1990). Justice and the politics of difference. Princeton, NJ: Princeton University Press.

Yuval-Davis, Nira, \& Floya Anthias, (Eds). (1989). Woman-nation-state. Basingstoke: Macmillan Press. 